\title{
An intragenic Taql polymorphism in the faciogenital dysplasia (FGD1) locus, the gene responsible for Aarskog syndrome
}

Received: 15 May 1995

\begin{abstract}
A TaqI polymorphism, located in intron 4 of the faciogenital dysplasia ( $F G D 1$ ) gene, the gene responsible for Aarskog syndrome, is described. FGD/ encodes a putative Rho/Rac guanine nucleotide exchange factor involved in mammalian morphogenesis. The identification of an intragenic polymorphism will facilitate the accurate carrier detection of individuals at risk for Aarskog syndrome.
\end{abstract}

Description. The FGDl probe is a $3.85-\mathrm{kb}$ EcoRI cDNA insert, denoted as pFCF3.85, that encodes the complete open reading frame of the faciogenital dysplasia gene, the gene responsible for Aarskog syndrome (Pasteris et al. 1994).

PCR primers. E4-P9: 5'TGAGGCCTCCCGCTGCCTGTTTC-3'. E5-P21: 5'-CTGATCCAGGAGATGGAGCCTGG-3.

Polymorphism. Used as a probe to perform hybridization analyses of TaqI-digested genomic DNA, probe pFCF3.85 detected two alleles: $\mathrm{Al}, 6.0 \mathrm{~kb}$ and $\mathrm{A} 2,3.8 \mathrm{~kb}$. The 6.0 $\mathrm{kb}$ fragment represented the $3.8 \mathrm{-kb}$ fragment (which included exon 4) and its adjacent 2.2-kb TaqI fragment (which included exon 5). To facilitate analysis, a PCR strategy was generated to investigate the presence or $a b$ -

\footnotetext{
N. G. Pasteris - J. L. Gorski

Department of Human Genetics and Pediatrics and Communicable Diseases,

University of Michigan Medical Center,

Ann Arbor, MI 48109-0688, USA

J. L. Gorski (区)

Pediatrics and Communicable Diseases,

Division of Pediatric Genetics,

University of Michigan Medical Center,

Ann Arbor, MI 48109-0688, USA
}

sence of the polymorphic TaqI site in intron 4. Genomic DNA was amplified using oligonucleotide primers directed against FGD1 exons 4 and 5. The polymorphism was identified by digesting the resulting $1.7-\mathrm{kb}$ PCR product with TaqI; upon digestion, products containing the TaqI site yielded $1.2-\mathrm{kb}$ and $0.5-\mathrm{kb}$ fragments.

Allelic frequency. Estimated from 84 chromosomes of unrelated individuals ( $40 \mathrm{CEPH}$ females and 2 random unrelated females). $\mathrm{A} 1=0.13 ; \mathrm{A} 2=0.87$.

Chromosomal localization. The FGD1 gene was localized to region Xp11.21 by somatic cell and radiation hybrid analyses (Pasteris et al. 1994).

Mendelian inheritance. Mendelian X-linked inheritance was observed in one family of five individuals.

$P C R$ conditions. Amplifications were performed in 50- $\mu 1$ volumes containing $50 \mathrm{mM} \mathrm{KCl}, 10 \mathrm{mM}$ Tris- $\mathrm{HCl}, \mathrm{pH}$ $8.0,10 \mathrm{mg} / \mathrm{ml} \mathrm{BSA}, 1.5 \mathrm{mM} \mathrm{MgCl}, 200 \mu M$ each of dATP, dGTP, dCTP, and dTTP, 100 ng of genomic DNA, $0.5 \mu M$ primers, and $2.5 \mathrm{U}$ AmpliTaq (Perkin Elmer/Cetus). Amplifications were performed in a DNA thermal cycler 480 (Perkin Elmer/Cetus); after an initial 10-min denaturation cycle $\left(94^{\circ} \mathrm{C}\right), 34$ cycles followed: $94^{\circ} \mathrm{C}$ denaturation $1 \mathrm{~min}, 65^{\circ} \mathrm{C}$ annealing $1 \mathrm{~min}, 72^{\circ} \mathrm{C}$ extension $2 \mathrm{~min}$, with a final extension of $10 \mathrm{~min}$ at $72^{\circ} \mathrm{C}$.

Acknowledgements The work was supported, in part, by the March of Dimes Birth Defects Foundation basic science grant 193-0326 and National Institutes of Health grant NS-30771 to J.L.G.

\section{References}

Pasteris NG, Cadle A, Logie LJ, Porteous MEM, Schwartz CE, Stevenson RE, Glover TW, Wilroy R, Gorski JL (1994) Isolation and characterization of the faciogenital dysplasia (Aarskog-Scott syndrome) gene: a putative Rho/Rac guanine nucleotide exchange factor. Cell $79: 669-678$ 